\title{
Water scarcity under various socio-economic pathways and its potential effects on food production in the Yellow River basin
}

\author{
Yuanyuan Yin ${ }^{1}$, Qiuhong Tang ${ }^{1,2}$, Xingcai Liu ${ }^{1}$, and Xuejun Zhang ${ }^{1}$ \\ ${ }^{1}$ Key Laboratory of Water Cycle and Related Land Surface Processes, Institute of Geographic Sciences \\ and Natural Resources Research, Chinese Academy of Sciences, Beijing, China \\ ${ }^{2}$ University of Chinese Academy of Sciences, Beijing, China \\ Correspondence to: Qiuhong Tang (tangqh@igsnrr.ac.cn)
}

Received: 22 April 2016 - Discussion started: 25 April 2016

Revised: 8 January 2017 - Accepted: 11 January 2017 - Published: 9 February 2017

\begin{abstract}
Increasing population and socio-economic development have put great pressure on water resources of the Yellow River (YR) basin. The anticipated climate and socioeconomic changes may further increase water stress. Many studies have investigated the changes in renewable water resources under various climate change scenarios, but few have considered the joint pressure from both climate change and socio-economic development. In this study, we assess water scarcity under various socio-economic pathways with emphasis on the impact of water scarcity on food production. The water demands in the 21 st century are estimated based on the newly developed shared socio-economic pathways (SSPs) and renewable water supply is estimated using the climate projections under the Representative Concentration Pathway (RCP) 8.5 scenario. The assessment predicts that the renewable water resources would decrease slightly then increase. The domestic and industrial water withdrawals are projected to increase in the next a few decades and then remain at the high level or decrease slightly during the 21 st century. The increase in water withdrawals will put the middle and lower reaches in a condition of severe water scarcity beginning in the next a few decades. If $40 \%$ of the renewable water resources were used to sustain ecosystems, a portion of irrigated land would have to be converted to rain-fed agriculture, which would lead to a $2-11 \%$ reduction in food production. This study highlights the links between water, food and ecosystems in a changing environment and suggests that trade-offs should be considered when developing regional adaptation strategies.
\end{abstract}

\section{Introduction}

The Yellow River (YR) is the second-longest river in China and is regarded as the cradle of Chinese civilization. The YR plays an important role in the development of the regional economy as the major source of freshwater for a large amount of people living there. As of 2010, there were 113.7 million inhabitants and 12.6 million hectares of cultivated land in the basin (Yellow River Conservancy Commission, YRCC, 2013). In addition, the lower reaches of the river supply freshwater for 2.86 million hectares of irrigated area and a population of 54.73 million located outside the basin (Fu et al., 2004). Increasing population and socio-economic development have put great pressure on the water resources of the basin. Anticipated climate and socio-economic changes may further increase water scarcity. The water managers of the basin will face great challenges meeting the human and environmental requirements for water. This water crisis in the YR basin has received much attention for many years.

Climate change and human water use are two major reasons for water crisis in the YR basin (Fu et al., 2004; Tang et al., 2008a; Wang et al., 2012). Numerous studies have investigated the changes in water supply due to climate change. Since the 1950s, streamflow of the river has decreased partly because of the decrease in precipitation and increase in temperature (Tang et al., 2008b; Xu, 2011; Wang et al., 2012). Some recent studies showed that there has been a substantial recovery of natural runoff over the past decade as a response to changes in precipitation, radiation, and wind speed (Tang et al., 2013; Liu et al., 2014). Climate projections suggest that temperature will continue to rise, but renewable water 
resources might decrease over the next few decades (Leng et al., 2015). Renewable water resources of the YR are likely to decrease due to both precipitation decrease and temperature increase over the next few decades (Li et al., 2012; Davie et al., 2013; Haddeland et al., 2014). However, water resources might increase by the end of the 21 st century due to an increase in precipitation (Liu et al., 2011; Leng et al., 2015). The change in water availability under climate change suggests the need for adaptation.

Along with rapid economic development and population growth, water withdrawals from the YR basin for industrial and household use have increased significantly. Water consumption for irrigation has induced a streamflow decrease by about half in the past half century (Tang et al., 2007; Shi et al., 2012). The lower reaches of the YR frequently ran dry (i.e., no streamflow in the low flow season) in the 1980s and 1990s (Tang et al., 2008b). Thereafter, the YRCC implemented a water flow regulation rule, which enforced an upper limit on water withdrawals for the eight provinces that rely on water supply from the river (Cai and Rosegrant, 2004). The expected increase in economic prosperity together with a growing population, both within and outside of the basin, will increase water demand from the river and thus water scarcity may impose further constraints on development and social well being (Schewe et al., 2014). As water becomes increasingly scarce, there will be more competitions and conflicts among different water use sectors and regions (provinces). The current water flow regulation rule, which has been enforced since the late 1980s, might not be applicable in the 21 st century.

Many studies have investigated the changes in water supply under various climate change but few have considered the joint pressure from both climate change and socio-economic development (Tang and Oki, 2016). It becomes important to develop qualitative scenario storylines to assess future water scarcity in a changing environment at the regional scale. These storylines would facilitate assessment of the water use competitions among different sectors and regions and thus aid development of adaptation strategy for the river basin. A few studies have tried to describe the main characteristics of future climate change scenarios and development pathways at the global scale (Elliott et al., 2014; Schewe et al., 2014). These efforts, though important, are too coarse for vulnerability assessment at the regional scale in the following aspects. First, the global studies do not consider the water flow regulation rule implemented by the local river administration, which sets limits on water withdrawals for each subbasin. Second, the global studies usually set a strict criterion on discharge reduction for human water use such as $40 \%$ (Schewe et al., 2014) while human water use in the YR basin has already exceeded the criterion (YRCC, 2013). Third, the global studies often exhibit considerable biases in water supply assessment as most global models are not validated using streamflow observations. Fourth, the YR river supplies water for irrigation districts not only inside the river basin but also those located outside of the basin. The water demands outside the basin are generally not considered in the global scale assessments. In this study, we use streamflow observations in the YR basin to bias-corrected global model outputs (Ho et al., 2012; Hawkins et al., 2013), and present a multi-model analysis of water supply and demand narratives under different climate change scenarios and socio-economic pathways at the sub-basin scale (Fig. 1 and Table 1). The objectives of the analysis are (i) to describe the water supply and demand changes in a changing environment, (ii) to identify the possible time horizon when current management practices may no longer be sustainable, (iii) to investigate the contributions of different water demand sectors to water scarcity, and (iv) to assess the potential impacts of water scarcity on agricultural production.

\section{Study area and data}

\subsection{Study area}

The YR originates from the northern foothills of the Tibetan Plateau, runs through nine provinces and autonomous regions, and discharges into the Bohai Gulf (Fig. 1). Total area of the basin is $75200 \mathrm{~km}^{2}$. The YR basin lies in a temperate continental climate zone, and most parts of the basin belong to arid or semi-arid regions. The mean annual temperature in 1981-2010 ranges spatially from -5 . to $15 .{ }^{\circ} \mathrm{C}$ in the basin, and it increases from north to south as a consequence of the decrease in latitude to the south (Fig. 2a). Precipitation has large spatial variation within the whole river basin. The mean annual precipitation in 1981-2010 ranges spatially from 60 to $900 \mathrm{~mm}$ in the basin, and shows an increasing trend from northwest to southeast (Fig. 2b). The temperature and precipitation are projected to increase during the 21 st century under the Representative Concentration Pathway (RCP) 8.5 emission scenario (see Fig. S1 in the Supplement).

There are six land cover types in the basin (Fig. 2c). The dominant land cover types are grasslands $(47.6 \%)$, croplands $(26.1 \%)$, and forest and shrublands (13.4\%). The urban and built-up lands are concentrated along the river. The croplands are mainly distributed in the lower reach of the YR. The land cover changes influence the hydrological cycle (Tang et al., 2008b, 2012), and may alter runoff (Sterling et al., 2013). However, interactions among land cover change, climate change, and hydrological cycle are complicated. To focus on runoff responses to climatic variations, the fixed land cover map was used in this study.

In 2010, the population within the basin boundary was more than 100 million, representing about $9 \%$ of China's population. The basin's gross domestic product (GDP) represented $8 \%$ of China's GDP in 2010. Both population and GDP are concentrated along the river (Fig. $2 \mathrm{~d}$ and e). The projected population increases first and then decreases during the 21st century (see Fig. S2a in the Supplement). China's 
Table 1. The eight sub-basins of the Yellow River (YR) basin.

\begin{tabular}{llrrrrl}
\hline Sub-basins & & $\begin{array}{r}\text { Area } \\
\left(\times 10^{3} \mathrm{~km}^{2}\right)\end{array}$ & $\begin{array}{r}\text { Water use } \\
\text { proportion }(\%)\end{array}$ & $\begin{array}{r}\text { Irrigated } \\
\text { area }\left(\mathrm{km}^{2}\right)\end{array}$ & $\begin{array}{r}\text { Rain-fed } \\
\text { area }\left(\mathrm{km}^{2}\right)\end{array}$ & Note \\
\hline Upper reaches & I & 127 & 0.57 & 219 & 27 & Above LYX station \\
& II & 87 & 8.23 & 2680 & 1706 & LYX to LZ \\
\multirow{5}{*}{ Middle reaches } & III & 157 & 37.45 & 23692 & 2106 & LZ to HKZ \\
& IV & 107 & 3.5 & 1591 & 3940 & HKZ to LM \\
& V & 185 & 16.64 & 25422 & 12311 & LM to SMX \\
Lower reaches & VI & 40 & 6.16 & 5717 & 2956 & SMX to HYK \\
& VII & 50.6 & 27.2 & 42824 & 2430 & HYK to LJ, including irrigation \\
& & & & & & districts outside the basin but \\
receiving water from YR \\
Endorheic basin
\end{tabular}

Note: the sub-basins and names of hydrological stations are given in Fig. 1.

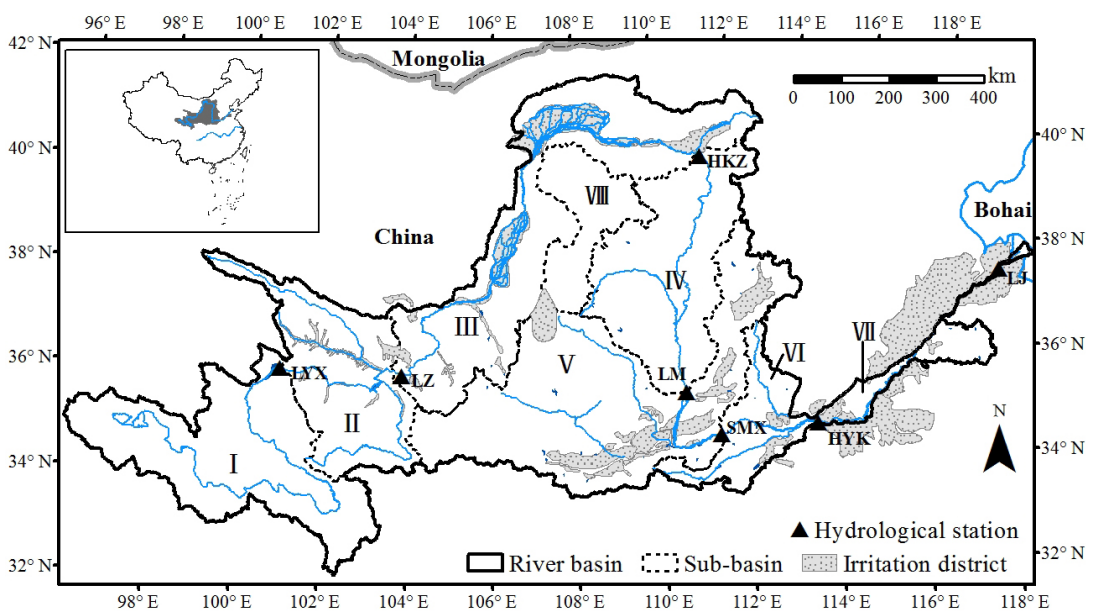

Figure 1. The Yellow River (YR) basin, the eight sub-basins, and location of Longyangxia (LYX), Lanzhou (LZ), Hekouzhen (HKZ), Longmen (LM), Sanmenxia (SMX), Huanyuankou (HYK), and Lijin (LJ) hydrological stations. The insert panel shows the location of the YR basin in China.

population has been greatly affected by its fertility policy (Peng, 2011). Under the current fertility policy, China's population would continue to grow, and then begin to decrease as the aging of the population accelerates (Chen and Liu, 2009; Peng, 2011). The range of projected population at the end of the 21 st century varies from 50 million to more than 100 million, with shared socio-economic pathway (SSP) 5 at the bottom of the range and SSP3 at the top. The range of projected GDP at the end of the 21st century varies from 21000 billion Yuan to more than 40000 billion Yuan. SSP5, with its focus on development, has the highest GDP projections and SSP3, representing the scenario with lowest international cooperation, has the lowest income projection (O'Neill et al., 2017).

\subsection{Data}

The data used in this study are summarized in Table 2 . The simulated runoff data for the period 1971-2099, and the simulated irrigation water use and crop yield data for the period 1981-2099 were obtained from the Inter-Sectoral Impact Model Intercomparision Project (ISI-MIP; Warszawski et al., 2014). These simulated data were provided at a spatial resolution of $0.5^{\circ} \times 0.5^{\circ}$. The runoff data were produced by 10 global gridded hydrological models (GGHMs), namely, DBH, H08, LPJmL, MacPDM, MATSIRO, MPIHM, PCR-GLOBWB, VIC, WaterGAP, and WBM (see Table $\mathrm{S} 1$ in the Supplement). The irrigation water use and crop yield data were produced by six global gridded crop models (GGCMs), namely, EPIC, GEPIC, LPJmL, LPJGUESS, pDSSAT, and PEGASUS (see Table S2 in the Supplement). Forcing data, bias-corrected by the ISI-MIP team for the GGHMs and GGCMs, were derived from climate projections of five global climate models (GCMs), namely, HadGEM2-ES, IPSL-CM5A-LR, MIROC-ESMCHEM, GFDL-ESM2M, and NorESM1 (see Table S3 in the Supplement) under the RCP 8.5 scenario (Warszawski 


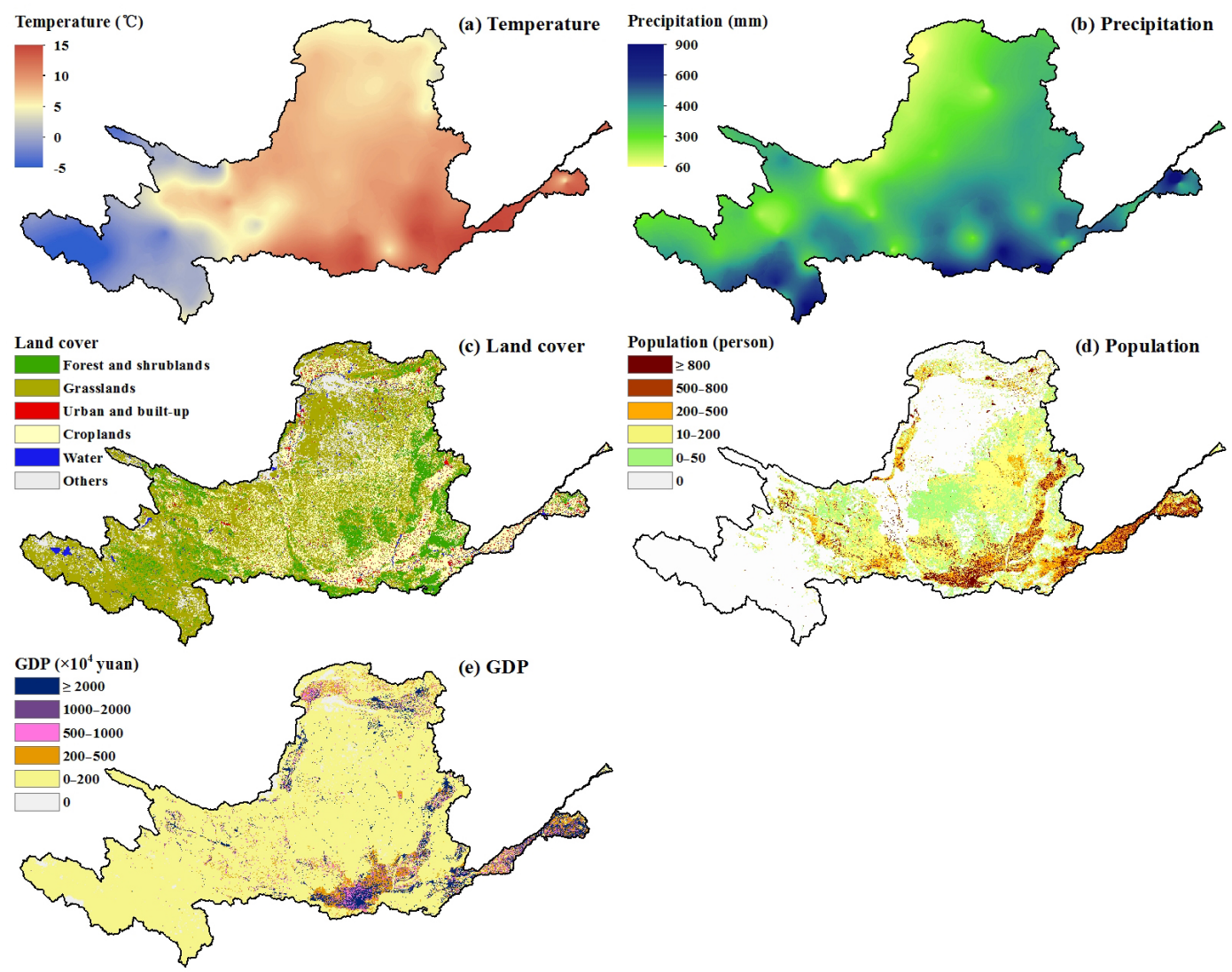

Figure 2. (a) Mean temperature (1981-2010), (b) annual mean precipitation (1981-2010), (c) land cover in 2010, (d) population in 2010, and (e) gross domestic product (GDP) in 2010 in the YR basin.

Table 2. Datasets used in this study.

\begin{tabular}{|c|c|c|c|}
\hline & Datasets & $\begin{array}{l}\text { Spatial and temporal } \\
\text { resolution }\end{array}$ & Source \\
\hline \multirow{4}{*}{\multicolumn{2}{|c|}{$\begin{array}{l}\text { Simulated runoff data } \\
\text { Simulated yield data } \\
\text { Simulated irrigation water data } \\
\text { Rain-fed and irrigation area data }\end{array}$}} & $0.5^{\circ} \times 0.5^{\circ}, 1971-2099$ & \\
\hline & & $0.5^{\circ} \times 0.5^{\circ}, 1971-2099$ & The Inter-Sectoral Impact Model \\
\hline & & $0.5^{\circ} \times 0.5^{\circ}, 1971-2099$ & Intercomparison Project (ISI-MIP) \\
\hline & & $0.5^{\circ} \times 0.5^{\circ}, 2000$ & \\
\hline \multirow[t]{3}{*}{ Population data } & $1 \mathrm{~km}$ grid population dataset of China & $1 \mathrm{~km} \times 1 \mathrm{~km}, 2005$ & $\begin{array}{l}\text { Institute of Geographic Sciences and } \\
\text { Natural Resources Research }\end{array}$ \\
\hline & Historical population data of China & Country, 1981-2013 & National Bureau of Statistics of China \\
\hline & SSP population data* & $0.5^{\circ} \times 0.5^{\circ}, 2010-2099$ & ISI-MIP \\
\hline \multirow[t]{3}{*}{ GDP data } & $1 \mathrm{~km}$ grid GDP dataset of China & $1 \mathrm{~km} \times 1 \mathrm{~km}, 2005$ & $\begin{array}{l}\text { Institute of Geographic Sciences and } \\
\text { Natural Resources Research }\end{array}$ \\
\hline & Historical GDP data of China & Country, 1981-2013 & National Bureau of Statistics of China \\
\hline & SSP GDP data* & Country, 2010-2099 & $\begin{array}{l}\text { Organization for Economic Co-operation } \\
\text { and Development (OECD) }\end{array}$ \\
\hline \multicolumn{2}{|c|}{ Official exchange rate data } & Country, 2005 & World Bank \\
\hline \multicolumn{2}{|c|}{ Observed runoff data } & $1971-2000$ & $\begin{array}{l}\text { Hydrological Bureau of the Ministry } \\
\text { of Water Resources of China }\end{array}$ \\
\hline
\end{tabular}

\footnotetext{
* SSP is short for shared socio-economic pathways.
} 
et al., 2014). The global irrigated and rain-fed crop area data (MIRCA2000), which consist of all major food crops, such as wheat, rice, maize, and soybean, were also obtained from ISI-MIP. The MIRCA2000 dataset refers to the crop area over the period of 1998-2002 (Portmann et al., 2010). According to the survey by the Ministry of Water Resources (MWR) of China, the cropland area of the YR basin in the 2000s is 16 million ha. The MIRCA2000 dataset shows that the cropland area is 16.27 million ha, a value quite close to the MWR estimate. Although the cropland area may change in the future due to local adaptation to environmental change, the projection of land use change is beyond the scope of this paper. The cropland map is fixed throughout the 21 st century in this study.

The gridded population and GDP datasets over China were provided by the Institute of Geographic Sciences and Resources Research (IGSRR), Chinese Academy of Sciences (CAS). The population and GDP datasets refer to the conditions in 2005 (Fu et al., 2014; Huang et al., 2014). The datasets were developed based on remote-sensing-derived land use data and the statistical population and GDP data of each county in China. The population and GDP data were provided with a spatial resolution of $1 \mathrm{~km}$ and were resampled to $0.5^{\circ}$ in this study with ArcGIS. The annual total population and GDP data of China during 1981-2013 were obtained from the National Bureau of Statistics of China (NBC). Using a simple linear downscaling method (Gaffin et al., 2004), we downscaled the annual total population and GDP data to the gridded maps. The future water demand should be closely related to the growth of GDP and population in the basin, and the SSPs offer the possibility for describing different conditions in terms of future sectoral water demand. Quantitative projections for population and GDP were developed for the 2010-2099 period based on the SSP Scenario Database, available at https://secure.iiasa. ac.at/web-apps/ene/SspDb. The population and GDP projections were provided at country level at 5-year intervals. The country-level population data were gridded to $0.5^{\circ}$ according to the 2010 Gridded Population of the World (GPWv3) dataset provided by the Center for International Earth Science Information Network (CIESIN), Columbia University. The country-level GDP data were provided in US dollars at 5-year intervals. The GDP data were converted to Chinese Yuan using the official exchange rate provided by the World Bank. The GDP data from the SSP Scenario Database were regridded to the $0.5^{\circ} \mathrm{GDP}$ of China grid and were linearly interpolated in time to obtain annual values (Gaffin et al., 2004). The assumption underlying the downscaling method is that the annual growth rate of GDP at each grid, at any year, is equal to the growth rate of China. The observed runoff data over 1971-2000 of four major hydrologic stations at the main stream of the YR (Lanzhou, LZ; Longmen, LM; Sanmenxia, SMX; and Huanyuankou, HYK) were collected from the Hydrological Year Book of the Ministry of Water Resources of China.

\section{Method}

The river basin was divided into eight sub-basins in order to understand the regional patterns of water abundance and scarcity (Fig. 1). The area of sub-basins varies from 40000 to $185000 \mathrm{~km}^{2}$ (Table 1). There are seven sub-basins along the main stream of the basin and one endorheic basin (subbasin VIII) that does not flow to the main stream of the river. Because the irrigation districts located outside of the basin in lower reaches get their water supply from the river, the subbasin in the lowest reaches (sub-basin VII) consists of one part in the river basin and these irrigation districts.

The mean annual runoff, including both the subsurface and surface runoff, is assumed to be the renewable water resources (Oki and Kanae, 2006). Because the bias of GGHMs is usually large (Hattermann et al., 2017), we used the streamflow observations at the YR basin to bias correct the model simulated runoff (see "Supplemental Methodology" in the Supplement). We compared the bias-corrected runoff of 10 GGHMs with the streamflow observations at the four selected hydrological stations (see Fig. S3 in the Supplement). The bias-corrected runoff can reproduce the streamflow well in the reference period (1971-2000). The bias-corrected runoff was aggregated for each sub-basin and the river basin as a whole (see Fig. S4 in the Supplement). In order to maintain the river in a desired environmental condition, we assumed that only a part of the renewable water resources could be appropriated by humans. The net water withdrawal, i.e., water withdrawal minus return flow, accounts for $53 \%$ of renewable water resources in the $1980 \mathrm{~s}$ (Zhang et al., 2004) and $72 \%$ in the 2010s (YRCC, 2013). Annual water supply was estimated as annual runoff multiplied by the ratio of human water appropriation (RHWA); i.e., the proportion of renewable water resources that is allowed to be used by humans. Because water supply is largely determined by the RHWA, water supply was estimated with RHWA values of 50,60, and $70 \%$. The water flow regulation rule currently implemented by YRCC (YRCC, 2013) sets the upper limit on water withdrawals for each sub-basin. According to the rule, the maximum water use proportion is prescribed for each sub-basin (Table 1). The annual water supply was calculated for each GCM-GGHM pair. There were 5 GCMs and 10 GGHMs, making 50 model pairs. The multi-model-ensemble median of water supply from all the available model pairs was calculated.

On the water demand side, the consumptive agricultural, domestic, and industrial water demands were considered. Agricultural water demand consists of the demands for irrigation and livestock. As the livestock demand is relatively small and the related statistical data were unavailable in the basin (YRCC, 2013), only irrigation demand was considered. The irrigation water demand was estimated by the GGCM. Table S2 shows an overview of the six GGCMs. Four crops, i.e., wheat, rice, maize, and soybean, were taken into account because these crops accounted for over $80 \%$ of total cropland 
area in the YR basin. The irrigation water demands were aggregated for each sub-basin and the river basin as a whole to get irrigation water withdrawal (IrrWW). The multi-modelensemble median of IrrWW from all the available GCMGGCM pairs (five GCMs $\times$ six GGCMs) was calculated.

Net domestic and industrial water withdrawals were linked to the main driving forces of water in the domestic and industrial sectors, i.e., population, GDP, and electricity production (Alcamo et al., 2003). Following Hanasaki et al. (2013a), the annual net domestic water withdrawal was calculated using Eq. (1).

$W_{\text {dom }}=\operatorname{Pop} \times\left(i_{\text {dom }, t 0}+s_{\text {dom, cat }} \times(t-t 0)\right) \times 0.365$,

where $W_{\text {dom }}$ is the net domestic water withdrawal $\left(\mathrm{m}^{3} \mathrm{yr}^{-1}\right)$, Pop is the population, $i_{\mathrm{dom}, t 0}$ is the domestic water intensity for the base year $\left(\mathrm{L} \mathrm{day}^{-1}\right.$ person $\left.{ }^{-1} \mathrm{yr}^{-1}\right), s_{\text {dom, cat }}$ is the domestic water intensity change rate $\left(\mathrm{L}\right.$ person ${ }^{-1} \mathrm{day}^{-1} \mathrm{yr}^{-1}$ ), and the multiplier 0.365 is applied for unit conversion.

Industrial water use includes two main components: water withdrawal for the manufacturing sector and for cooling the thermoelectric plants in the electricity sector. The manufacturing water withdrawal is positively correlated with the economic metric manufacturing gross value added (Dziegielewski et al., 2002). Following Flörke et al. (2013) and Wada et al. (2016), the annual net industrial water withdrawal depends on the value added of manufacturing sectors and the water use intensities (Eq. 2).

$W_{\text {ind }}=\operatorname{GDP}_{\text {manu }} \times i_{\text {ind }, t 0} \times\left(1-s_{\text {ind,cat }}\right)^{(t-t 0)}$,

where $W_{\text {ind }}$ is the net industrial water withdrawal $\left(\mathrm{m}^{3} \mathrm{yr}^{-1}\right)$, $\mathrm{GDP}_{\text {manu }}$ is the value added of manufacturing sectors (Chinese Yuan), $i_{\text {ind, } t 0}$ is the industrial water intensity for the base year $\left(\mathrm{m}^{3}\right.$ per 10000 Yuan), and $s_{\text {ind,cat }}$ is the industrial water intensity change rate $(\%)$. The value added of manufacturing sectors is calculated by multiplying the GDP projection by the share of manufacturing gross value added in total GDP for non-OECD countries from the UNEP GEO4 Driver Scenarios (Hughes, 2005). Change in water withdrawal for thermal power industry is not considered in this study for two reasons. First, water conservation technology, such as dry cooling has been widely adopted in northern China and thermal power industry, is not the major water user in the YR basin (Zhang et al., 2016). Second, the projection of future change is subject to large uncertainties as increase in demand is complicated with the advanced water conservation technologies (Zhang et al., 2016).

The change rates of domestic and industrial water intensity are dependent on the technology scenario of the SSPs. A high-technology scenario was set for SSP1 and SSP5, medium for SSP2, and low for SSP3 and SSP4 (O'Neill et al., 2017). For domestic water use, SSP1 and SSP5 would be more efficient, whereas SSP3 and SSP4 would be less efficient; SSP2 would be intermediate between the two groups (Hanasaki et al., 2013a). The domestic water intensity change rate was proposed in Table S4 (Hanasaki et al., 2013a). For industrial water use, the change rate is set at $1.1 \%$ for SSP1 and SSP2, $0.6 \%$ for SSP2 and SSP4, and $0.3 \%$ for SSP3 (Wada et al., 2016). In this study, the base year is 2005 . The domestic water intensity for the base year is $83.6\left(\mathrm{~L} \mathrm{day}^{-1}\right.$ person $\left.^{-1} \mathrm{yr}^{-1}\right)$ while the industrial water intensity for the base year is $205.4\left(\mathrm{~m}^{3}\right.$ per 10000 Yuan) in the YR basin.

Annual water demand was calculated as the sum of net water withdrawal requirement for agricultural, domestic, and industrial uses. In order to measure water supply stress, the water supply stress index (WaSSI) was used. WaSSI is defined as the ratio of annual water demand to annual water supply for a specific watershed. It measures whether water supplies are sufficient for all net withdrawal requirements within a watershed to be met concurrently. The WaSSI was calculated for each sub-basin and the whole basin to assess the water abundance/scarcity condition. To investigate the contributions of different water demand sectors to water scarcity, WaSSI was calculated for the major sectors, i.e., domestic, industrial, and agricultural (denoted as irrigation hereafter because only irrigation was considered) sectors, at the end of the 21 st century. If the WaSSI is projected to be greater than 1 , water resources cannot sustain the socio-economic development and water scarcity occurs. The greater the WaSSI value is, the greater water scarcity is expected. We assume that irrigated agriculture has the lowest priority of all water consumers under water scarcity. If water scarcity occurs in a given year for a specific watershed, irrigation will be constrained by reducing the irrigated fraction of the cropland (Elliott et al., 2014); the agricultural production of the watershed, calculated as calorie content of the major crop yields, will be the sum of production over the expanded rain-fed fraction of the cropland and the shrunken irrigated fraction. If water is sufficient in a given year for a given sub-basin, we will assume that no rain-fed areas will be converted for irrigation.

The water supply and demands were assessed for each year during 1981-2099. However, the 30-year moving averages were also computed and illustrated. The 30 -year window ensures that year-to-year variability does not dominate the signal. The center year of the 30-year moving average was used to denote the 30-year period. For example, the average of the historical period of 1981-2010 was denoted as 1995.

\section{Results}

\subsection{Changes of water supply}

Figure 3 shows the estimated water supply in the YR basin and eight sub-basins in the 21st century. With an increase in the RHWA, the water supply is projected to increase during 


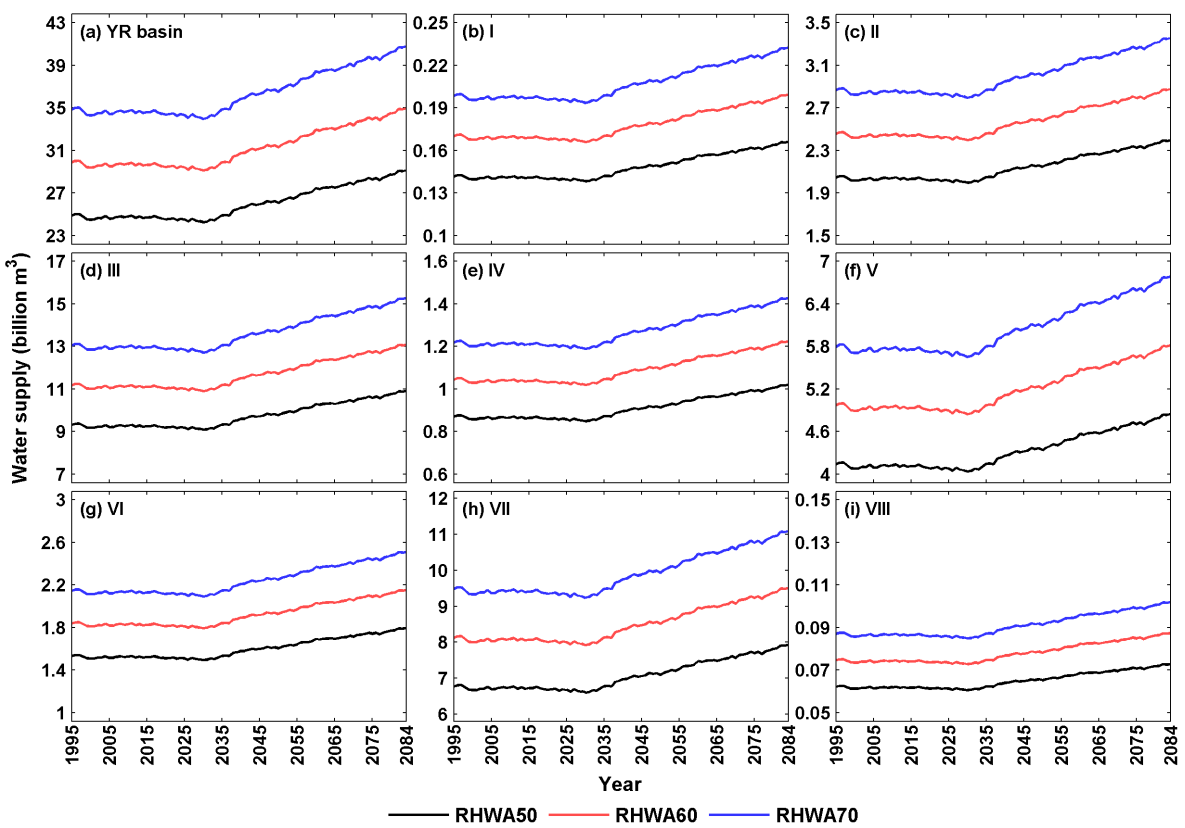

Figure 3. Annual water supplies in the YR basin and eight sub-basins during the 21st century. The water supply was estimated with RHWA values of 50,60 , and $70 \%$, respectively.

the 21 st century in the YR basin. The average water supply is $24.7,29.8$, and 34.8 billion $\mathrm{m}^{3}$ per year during the historical period under three RHWA - 50, 60 and $70 \%$. The water supply is projected to decrease slightly from 19952035 due to an increase in air temperature (see Fig. S1 in the Supplement), and is projected to increase from 2036 to 2084 due to an increase in precipitation under all RHWAs (see Fig. S1 in the Supplement). The result is consistent with the conclusions from Zhao et al. (2009). The water supply is projected to be $29.1,34.9$, and 40.6 billion $\mathrm{m}^{3}$ per year at the end of the 21st century under RHWA50, RHWA60, and RHWA70, respectively, increasing by about $17.8 \%$ from that during the historical period. The water supply is projected to first decrease and then increase in all the sub-basins during the 21 st century. The average water supply of sub-basin III has the maximum value of 9.3 billion $\mathrm{m}^{3}$ per year during the historical period and rises to 10.9 billion $\mathrm{m}^{3}$ per year by the end of the 21 st century under RHWA50. The average water supply of sub-basin VIII has the minimum value of 0.06 billion $\mathrm{m}^{3}$ per year during the historical period and rises to 0.73 billion $\mathrm{m}^{3}$ per year by the end of the 21 st century under RHWA50.

\subsection{Changes of total and sectoral water demand}

Figures 4, S5, and S6 show the estimated total and sectoral (domestic, industrial, and irrigation) water demand in the YR basin and eight sub-basins under five SSPs in the 21st century. In the YR basin, the total water demand is projected to increase from 24 billion $\mathrm{m}^{3} \mathrm{yr}^{-1}$ in 1995 to close to
$27.8,33.1,23.8,30.0$, and 30.3 billion $\mathrm{m}^{3} \mathrm{yr}^{-1}$ in 2084 under SSP1, SSP2, SSP3, SSP4, and SSP5, respectively. This increase is primarily driven by the growth in the industrial water withdrawal, accounting for at least $32 \%$ of the total in 2084. Irrigation is the dominant water use sector during the period 1995-2084. Domestic water withdrawal is projected to increase before 2025, as both population and domestic water use intensities will increase, and then to decrease due to a decrease in population (see Fig. S2a in the Supplement). Industrial water withdrawal is projected to rapidly increase before 2050, as the value added of manufacturing sectors will increase (see Fig. S2b in the Supplement), and then is projected to decrease slightly due to a decrease in industrial water use intensities. The irrigation water withdrawal is projected to decrease from 20 billion $\mathrm{m}^{3} \mathrm{yr}^{-1}$ in 1995 to close to 17 billion $\mathrm{m}^{3} \mathrm{yr}^{-1}$ in 2084 under RCP 8.5 . Irrigation water withdrawal is projected to increase slightly during 19952030 , and is projected to decrease during 2031-2084. The total water demand, both domestic and industrial water withdrawals, are also projected to increase and then decrease in each sub-basin during the 21 st century under all SSPs. In the sub-basins III, V, VII, and VIII, although the industrial water withdrawal would increase rapidly, irrigation is always the dominant water use sector during the 21 st century. In the sub-basins I, II, IV, and V, the irrigation and domestic water withdrawal are the dominant water use sectors at the beginning of the 21 st century, while the industry would become the dominant water use sector after the 2030s. 


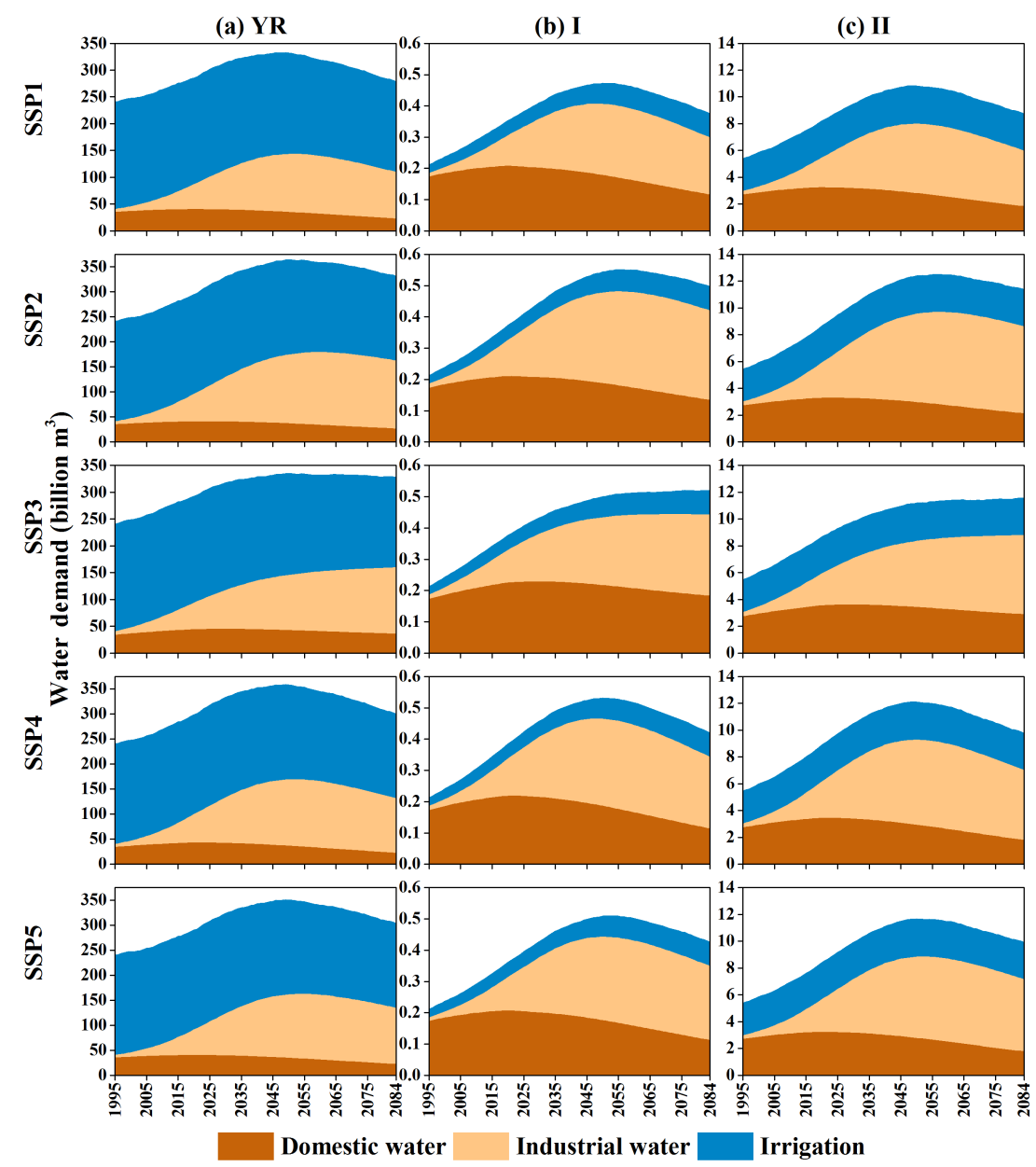

Figure 4. Estimated sectoral (domestic, industrial, and irrigation) and total annual water demand (million $\mathrm{m}^{3} \mathrm{yr}^{-1}$ ) in the $\mathrm{YR}_{\mathrm{R}} \mathrm{basin}$, and sub-basin I and II during the 21 st century.

\subsection{Water abundance/scarcity and sectoral contributions to water scarcity}

Figure 5 shows the average annual WaSSI for the YR basin and eight sub-basins throughout the 21st century under the five different SSPs. The WaSSI is projected to increase due to an increase in demand during the 21 st century. Under RHWA50, the YR basin is projected to have a WaSSI greater than 1 after 2000s for all SSPs, which means that water demand outstrips supply. The WaSSI is projected to decrease with an increase in the RHWA. Under RHWA70, water scarcity would not occur in the 21st century for all SSPs. The upper reaches of the YR basin (sub-basins I, II, and III) are projected to have a WaSSI less than 1, meaning that water supply would be more than water demand during the 21st century for all SSPs under all RHWAs. The endorheic basin in the YR basin (sub-basin VIII) is the only region in which the WaSSI is always larger than 1, meaning that the water would be scarce during the 21st century for all SSPs under all RHWAs. In the middle and lower reaches of the YR basin (sub-basins IV, V, VI, and VII), the WaSSI would begin to be large than 1 at the beginning of the 21st century under RHWA50. With an increase in the RHWA, water scarcity would occur later. If the RHWA reaches $70 \%$, water supply will be more than water demand during 1995-2084 in sub-basins IV under all SSPs.

Figure 6 shows the WaSSI calculated as the ratio of annual water demand and sectoral (domestic, industrial, and irrigation) water withdrawals to annual water supply under RHWA50 for the YR basin and eight sub-basins at the end of the 21st century under the five different SSPs. In the YR basin, the WaSSI calculated as annual water demand to water supply is larger than 1 under all SSPs except SSP1, meaning that the water scarcity would occur at the end of the $21 \mathrm{st}$ century. Among the three different water demand sectors, irrigation is projected to contribute most (about half) to WaSSI for all SSPs, and the domestic sector is projected to have the smallest contribution to WaSSI (less than 0.1) for all SSPs except SSP3. Both WaSSI and contributions from the water demand sectors to water scarcity would decrease with an in- 


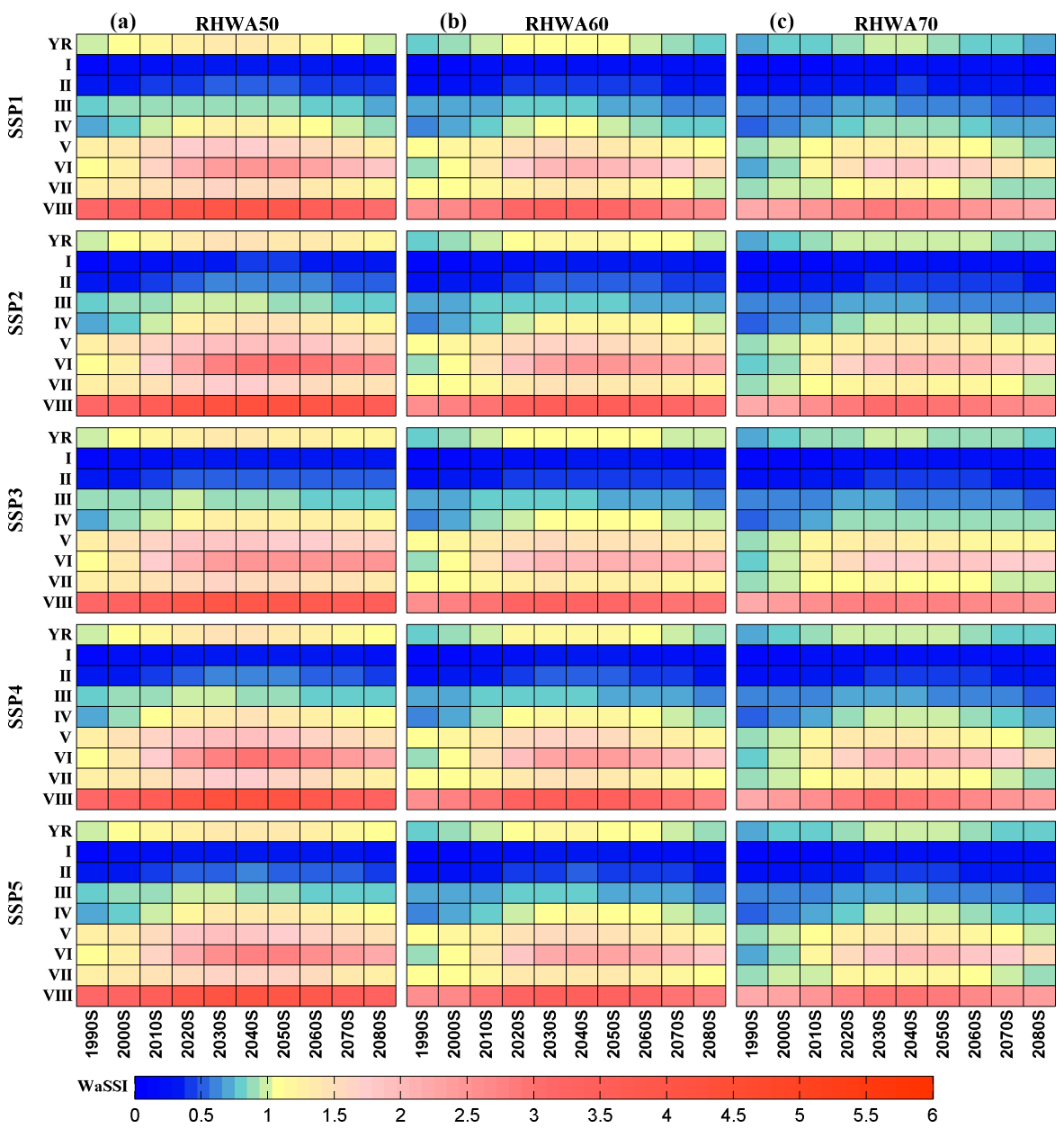

Figure 5. Average annual water supply stress index (WaSSI) for the YR basin and eight sub-basins throughout the 21 st century under five different SSPs. Water supply was estimated with an RHWA value of 50, 60, and $70 \%$ in the left, center, and right column, respectively. The WaSSI is calculated for each decade. Water scarcity occurs in a given basin if WaSSI is greater than 1 .

crease in the RHWA. With an increase in the RHWA, more water can be used to meet water demands. Consequently, WaSSI becomes smaller with higher RHWA (see Figs. S7 and S8 in the Supplement). In sub-basins III, V, VII, and III, irrigation is the main contributing factor to WaSSI, and the industrial sector is another important contributing factor. An increase in GDP would make the industrial sector become the main contributing factor to WaSSI for sub-basins I, II, IV, and VI. Because both population and GDP are concentrated in the middle and lower reaches, the estimated WaSSI is larger than one in those sub-basins, but smaller than one for the sub-basins in the upper reaches.

\subsection{Agricultural loss due to irrigation water scarcity}

The climate change and irrigation water shortage in the YR basin would have significant implications for the food security of these regions. Considering the $\mathrm{CO}_{2}$ fertilization effect, agricultural production will be enhanced by climate change, and is projected to increase by close to $15.1 \%$ by the middle of the 21 st century compared with production during the historical period in the YR basin (Fig. 7). Irrigation water scarcity could necessitate the reversion of cropland from irrigated to rain-fed management, and would lead to decreased agricultural production. Under RHWA50, irrigation water scarcity in the basin could necessitate the reversion of about half of the cropland from irrigated to rain-fed management by the middle of the 21 st century. Considering the $\mathrm{CO}_{2}$ fertilization effect, irrigation water scarcity would lead to $15.7,25.4,17.7,22.7$, and $21 \%$ of present-day total production reduction under SSP1, SSP2, SSP3, SSP4, and SSP5, respectively, in 2050 (Fig. 7). The change rate of production is projected to decrease with an increase in the RHWA. Under RHWA60, the reduction of agriculture production in 2050 might be $1-11 \%$ of present-day total production reduction. Under RHWA70, the reduction of agriculture production in 2050 would not occur under all SSPs. Considering the impacts of climate and water supply stress, the reduction 


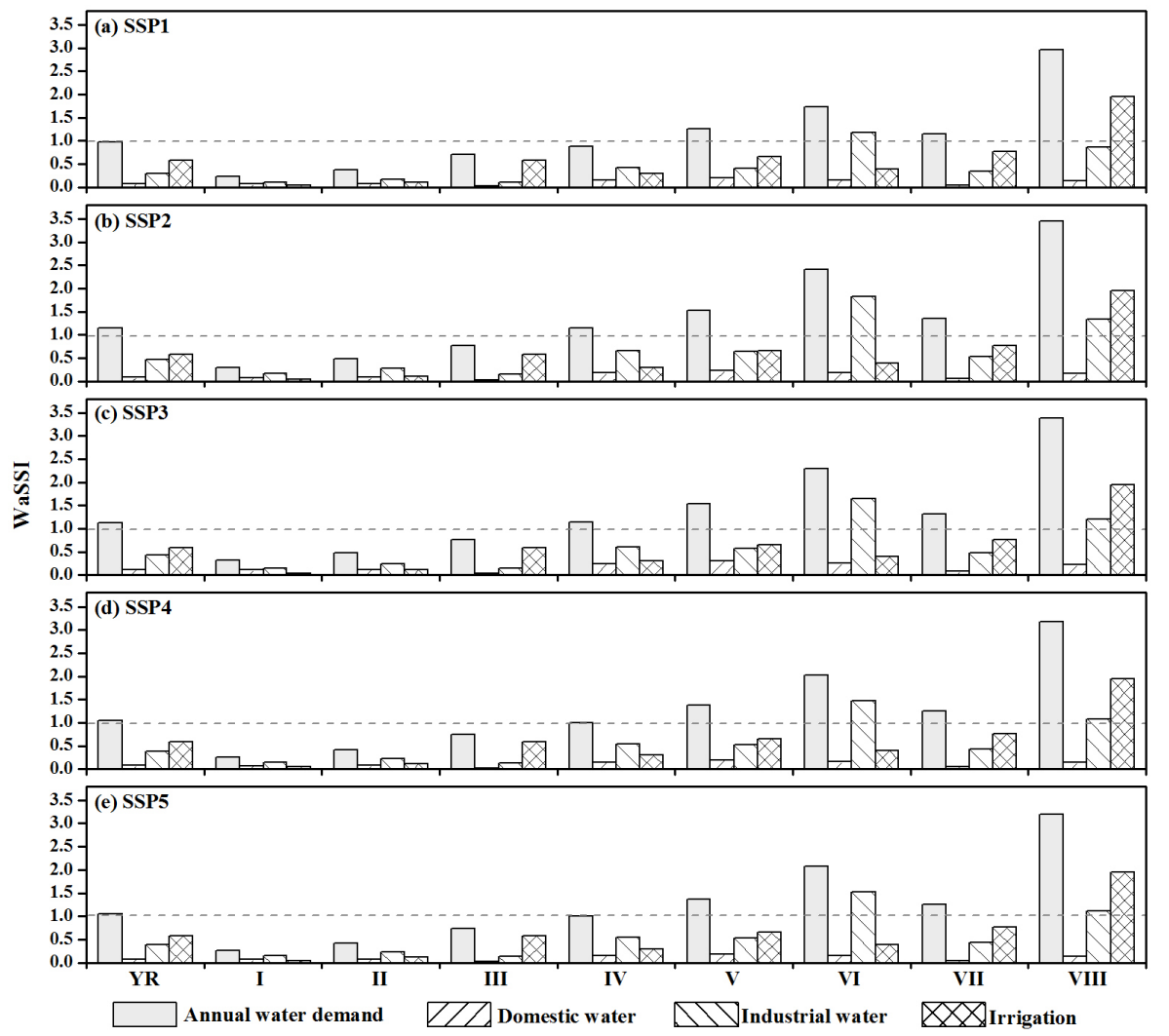

Figure 6. WaSSI calculated as the ratio of annual water demand and sectoral (domestic, industrial, and irrigation) water withdrawals to annual water supply for the YR basin and eight sub-basins at the end of the 21 st century under the five different SSPs. The annual water supply was estimated with an RHWA value of $50 \%$ (RHWA50).

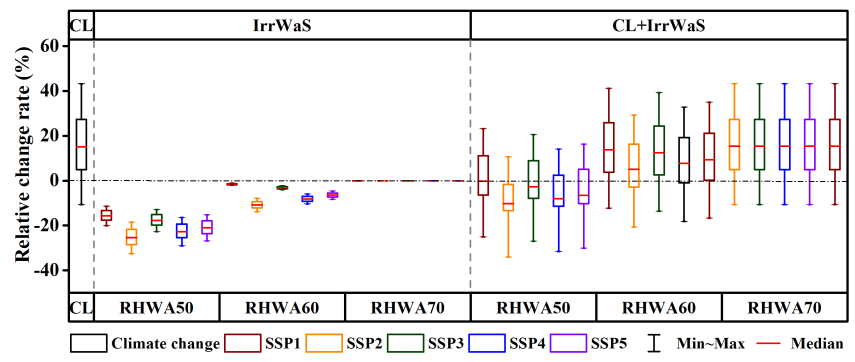

Figure 7. Comparison of relative change of agriculture production with only climate impact (CL), only irrigation water scarcity impact (IrrWaS), and combined climate and irrigation water scarcity impact $(\mathrm{CL}+\mathrm{IrrWaS})$ in the YR basin in the 2050s (\%).

of agriculture production in 2050 occurs for all SSPs under RHWA50. Under RHWA60 and RHWA70, the agriculture production is projected to increase under each SSP by the middle of the 21st century.

\section{Discussion}

The renewable water resources will be affected by projected changes in precipitation and temperature (Schewe et al., 2014), and in the RHWA. The water supply in the YR basin would first decrease and then increase due to the impact of temperature and precipitation changes over the 21 st century (see Fig. S1 in the Supplement). However, the true water shortage might be larger because the CMIP5 models may overestimate the magnitude of precipitation in the YR basin during the 21st century (Chen and Frauenfeld, 2014). The RHWA of the YR basin has increased to $75.6 \%$ during the beginning of the 21st century (Shi et al., 2012) from about $50 \%$ in 1980s (Zhang et al., 2004). An increase in RHWA tends to result in increase in water supply and reductions in irrigation water scarcity and loss of agriculture production (Figs. 1 and 7). Therefore, improvement of the RHWA could alleviate the water shortages in this region. However, because of the different geographical and economic conditions among the sub-basins, the impact of the RHWA should be considered when we analyze the water resources of the sub-basins.

To quantify the domestic and industrial water withdrawal is difficult because the future water withdrawals are influ- 
enced by a combination of social, economic, and political factors. However, a few hydrologic modeling frameworks have integrated methods to estimate the water withdrawals, e.g., H08 (Hanasaki et al., 2010, 2013a, b), PCR-GLOBWB (Wada et al., 2011, 2014, 2016), and WaterGAP (Flörke et al., 2013). The differences in these approaches result in significantly different projections even with the same set of scenario assumptions (Wada et al., 2016). Our study does not consider the change in water for the thermal power industry, which accounts for about $30 \%$ of industrial water use in the YR basin (Zhang et al., 2016); it might lead to an underestimation of the contribution of industrial water withdrawal to water scarcity.

With the currently implemented water flow regulation rule, water is projected to be scarce in sub-basins located in the middle and lower reaches of the YR basin characterized by a generally large population and GDP, whereas water is projected to be abundant in sub-basins located in the upper reaches of the YR basin characterized by a small population and GDP during the 21 st century. In order to alleviate the water shortages in the middle and lower reaches, a new water flow regulation rule should be adopted.

In order to solve the problem of water resources shortages in the more arid and industrialized northern China, the Southto-North Water Diversion Project has been undertaken. One aim of the project is to channel the fresh water from the Yangtze River in southern China to the YR basin (YRCC, 2013). By 2030, about 9.7 billion $\mathrm{m}^{3}$ of fresh water from the Yangtze River will have been drawn to the YR basin (YRCC, 2013). This could alleviate the water shortage in the YR basin to some degree.

\section{Conclusions}

In this study, we assessed the change in renewable water resources of the YR basin under climate change and the changes in domestic and industrial water withdrawals in the basin under socio-economic change in the 21 st century. The results show that the renewable water resources are projected to first slightly decrease and then increase in the YR basin and each sub-basin with an increase in temperature and precipitation in the 21 st century under RCP 8.5 . Irrigation is the dominant water use sector before the 2030s, but irrigation and industry sectors are the dominant water users thereafter. With social and economic development, domestic and water withdrawals are projected to increase first and then remain at a high level or decrease slightly during the 21 st century.

Water is always scarce in the endorheic basin, whereas water is always abundant in the sub-basins located in the upper reaches of the YR basin in the 21st century under all RHWAs and SSPs. Due to a water withdrawal increase in industrial sectors, the available water resources cannot sustain all water use sectors in the next few decades in the YR basin and the sub-basins located in the middle and lower reaches of the basin. The water resources shortage is most serious under SSP2, and the use of $60 \%$ renewable water resources cannot sustain all the water use sectors in the YR basin. With the three water demand sectors considered, the industrial water withdrawal is the main contributing factor to water scarcity in sub-basin I, II, IV, and V, whereas the irrigation water withdrawal is the main contributing factor to water scarcity in sub-basin III, V, VII, and VIII.

Although climate change may have a positive impact on agriculture through the $\mathrm{CO}_{2}$ fertilization effect in most regions of the YR basin (Yin et al., 2015), irrigation water scarcity would lead to the net loss of agricultural production. With the $\mathrm{CO}_{2}$ fertilization effect, if more than $40 \%$ of the renewable water resources are used to sustain ecosystems, a portion of irrigated land would have to be converted to rainfed agriculture, which would lead to a $2-11 \%$ reduction in food production. It should be noted that the change in water use for the thermal power industry was not considered in this study. This might cause underestimation of the water stress index. Nevertheless, this study highlights the linkage between water and food security in a changing environment in the YR basin, and suggests that a trade-off should be considered when developing regional adaptation strategies.

\section{Data availability}

The SSP population data and model outputs of GGCMs and GGHMs were provided by the Inter-Sectoral Impact Model Intercomparison Project (https://www.isimip.org, ISIMIP, 2016). The SSP GDP data were provided by Organization for Economic Co-operation and Development (http: //www.oecd.org/, OECD, 2016). The official exchange rate data of China were provided by the World Bank (http://data. worldbank.org/, World Bank, 2015). The historical population and GDP data of China were obtained from the National Bureau of Statistics of China (http://www.stats.gov.cn/tjsj/, NBSC, 2015). The $1 \mathrm{~km}$ grid population dataset and $1 \mathrm{~km}$ grid GDP dataset of China were provided by Data Center for Resources and Environmental Sciences, Chinese Academy of Sciences (http://www.resdc.cn, RESDC, 2015).

\section{The Supplement related to this article is available online at doi:10.5194/hess-21-791-2017-supplement.}

Competing interests. The authors declare that they have no conflict of interest. 
Acknowledgements. This research is supported by the National Natural Science Foundation of China (41425002), the Key Research Program of the Chinese Academy of Sciences (ZDRWZS-2016-6-4), and the National Youth Top-notch Talent Support Program in China. We would like to thank the anonymous reviewers and the editor for their valuable and constructive suggestions. Thanks are due to Huijuan Cui for her comments.

Edited by: L. Wang

Reviewed by: two anonymous referees

\section{References}

Alcamo, J., Döll, P., Henrichs, T., Kaspar, F., Lehner, B., Rösch, T., and Siebert, S.: Development and testing of the WaterGAP2 global model of water use and availability, Hydrolog. Sci. J., 48, 317-337, doi:10.1623/hysj.48.3.317.45290, 2003.

Cai, X. and Rosegrant, M. W.: Optional water development strategies for the Yellow River basin: Balancing agricultural and ecological water demands, Water Resour. Res., 40, W08S04, doi:10.1029/2003WR002488, 2004.

Chen, L. and Frauenfeld, O. W.: A comprehensive evaluation of precipitation simulations over China based on CMIP5 multimodel ensemble projections. J. Geophys. Res.-Atmos., 119, 5767-5786, doi:10.1002/2013JD021190, 2014.

Chen, W. and Liu, J. J.: Future population trends in China: 20052050. Centre of Policy Studies (COPS), Monash University, Wellington Road, Australia, 2009.

Davie, J. C. S., Falloon, P. D., Kahana, R., Dankers, R., Betts, R., Portmann, F. T., Wisser, D., Clark, D. B., Ito, A., Masaki, Y., Nishina, K., Fekete, B., Tessler, Z., Wada, Y., Liu, X., Tang, Q., Hagemann, S., Stacke, T., Pavlick, R., Schaphoff, S., Gosling, S. N., Franssen, W., and Arnell, N.: Comparing projections of future changes in runoff from hydrological and biome models in ISI-MIP, Earth Syst. Dynam., 4, 359-374, doi:10.5194/esd-4359-2013, 2013.

Dziegielewski, B., Sharma, S. C., Bik, T. J., Margono, H., and Yang, X.: Analysis of water use trends in the Unites States: 1950-1995. Special Report 28, Illinois Water Resources Center, University of Illinois, USA, 2002.

Elliott, J., Deryng, D., Müller, C., Frieler, K., Konzmann, M, Gerten, D., Glotter, M., Flörke, M., Wada, Y., Best, N., Eisner, S., Fekete, B. M., Folberth, C., Foster, I., Gosling, S. N., Haddeland, I., Khabarov, N., Ludwing, F., Masaki, Y., Olin, S., Rosenzweig, C., Ruane, A. C., Satoh, Y., Schmid, E., Stacke, T., Tang, Q., and Wisser, D.: Constraints and potentials of future irrigation water availability on agricultural production under climate change, P. Natl. Acad. Sci. USA, 111, 3239-3244, doi:10.1073/pnas.1222474110, 2014.

Flörke M., Kynast E., Bärlund I., Eisner S., Wimmer F., and Alcamo J.: Domestic and industrial water uses of the past 60 years as a mirror of socio-economic development: A global simulation study, Global Environ. Chang., 23, 144-156, doi:10.1016/j.gloenvcha.2012.10.018, 2013.

Fu, G. B., Chen, S. L., Liu, C. M., and Shepard, D.: Hydro-climatic trends of the Yellow River basin for the last 50 years, Climatic Change, 65, 149-178, doi:10.1023/B:CLIM.0000037491.95395.bb, 2004.
Fu, J. Y., Jiang, D., and Huang, Y. H.: $1 \mathrm{~km}$ grid population dataset of China (2005, 2010) (Supplement), Acta Geogr. Sin., 69, 136139, doi:10.3974/geodb.2014.01.06.V1, 2014.

Gaffin, S. R., Rosenzweig, C., Xing, X. S., and Yetman, G.: Downscaling and geo-spatial gridding of socio-economic projections from the IPCC Special Report on Emissions Scenarios (SRES), Global Environ. Chang., 14, 105-123, doi:10.1016/j.gloenvcha.2004.02.004, 2004.

Haddeland, I., Heinke, J., Biemans, H., Eisner, S., Flörke, M., Hanasaki, N., Konzmann, M., Ludwig, F., Masaki, Y., Schewe, J., Stacke, T., Tessler, Z. D., Wada, Y., and Wisser, D.: Global water resources affected by human interventions and climate change, P. Natl. Acad. Sci. USA, 111, 3251-3256, doi:10.1073/pnas.1222475110, 2014.

Hanasaki, N., Inuzuka, T., Kanae, S., and Okim, T.: An estimation of global virtual water flow and sources of water withdrawal for major crops and livestock products using a global hydrological model, J. Hydrol., 382, 232-244, doi:10.1016/j.jhydrol.2009.09.028, 2010.

Hanasaki, N., Fujimori, S., Yamamoto, T., Yoshikawa, S., Masaki, Y., Hijioka, Y., Kainuma, M., Kanamori, Y., Masui, T., Takahashi, K., and Kanae, S.: A global water scarcity assessment under Shared Socio-economic Pathways - Part 1: Water use, Hydrol. Earth Syst. Sci., 17, 2375-2391, doi:10.5194/hess-17-23752013, 2013a.

Hanasaki, N., Fujimori, S., Yamamoto, T., Yoshikawa, S., Masaki, Y., Hijioka, Y., Kainuma, M., Kanamori, Y., Masui, T., Takahashi, K., and Kanae, S.: A global water scarcity assessment under Shared Socio-economic Pathways - Part 2: Water availability and scarcity, Hydrol. Earth Syst. Sci., 17, 2393-2413, doi:10.5194/hess-17-2393-2013, 2013b.

Hattermann, F. F., Krysanova, V., Gosling, S., Dankers, R., Daggupati, P., Donnelly, C., Flörke, M., Huang, S., Motovilov, Y., Buda, S., Yang, T., Müller, C.,Leng, G., Tang, Q., Portmann, F. T., Hagemann, S., Gerten, D., Wada, Y., Masaki, Y., Alemayehu, T., Satoh, Y., and Samaniego, L.: Cross-scale intercomparison of climate change impacts simulated by regional and global hydrological models in eleven large river basins, Climatic Change, doi:10.1007/s10584-016-1829-4, accepted, 2017.

Hawkins, E., Osborne, T. M., Ho, C. K., and Challinor, A. J.: Calibration and bias correction of climate projections for crop modeling: An idealized case study over Europe, Agr. Forest Meteorol., 170, 19-31, 2013.

Ho, C. K., Stephenson, D. B., Collins, M., Ferro, C., and Brown, S.: Calibration strategies: A source of additional uncertainty in climate change projections, B. Am. Meteorol. Soc., 93, 21-26, doi:10.1175/2011BAMS3110.1, 2012.

Huang, Y. H., Jiang, D., and Fu, J. Y.: $1 \mathrm{~km}$ grid GDP data of China (2005, 2010) (Supplement), Acta Geogr. Sin., 69, 140143, doi:10.3974/geodb.2014.01.07.V1, 2014.

Hughes, B. B.: UNEP GEO4 diver scenarios (fifth draft), Josef Korbel School of International Studies, University of Denver, Colorado, USA, 2005.

ISI-MIP: The Inter-Sectoral Impact Model Inter-comparison Project, ISI-MIP Output Data, available at: https://www.isimip. org, last access: 12 November 2016.

Leng, G., Tang, Q., Huang, M., Hong, Y., and Ruby, L.: Projected changes in mean and interannual variability of surface 
water over continental China, Sci. China Ser. D, 58, 739-754, doi:10.1007/s11430-014-4987-0, 2015.

Li, L., Shen, H. Y., Dai, S., Xiao, J. S., and Shi, X. H.: Response of runoff to climate change and its future tendency in the source region of Yellow River, J. Geogr. Sci., 23, 431-440, doi:10.1007/s11442-012-0937-y, 2012.

Liu, L. L., Liu, Z. F., Ren, X. Y., Fischer, T., and Xu, Y.: Hydrological impacts of climate change in the Yellow River Basin for the 21st century using hydrological model and statistical downscaling model, Quatern. Int., 244, 211-220, doi:10.1016/j.quaint.2010.12.001, 2011.

Liu, X., Zhang, X.-J., Tang, Q., and Zhang, X.-Z.: Effects of surface wind speed decline on modeled hydrological conditions in China, Hydrol. Earth Syst. Sci., 18, 2803-2813, doi:10.5194/hess-18-2803-2014, 2014.

NBSC: National Bureau of Statistics of China, The historical population and GDP data of China, available at: http://www.stats.gov. cn/tjsj/, last access: 8 November 2015.

OECD: Organization for Economic Co-operation and Development, SSP Scenario Database-GDP, available at: http://www. oecd.org/, last access: 12 November 2016.

Oki, T. and Kanae, S.: Global hydrological cycles and world water resources, Science, 313, 1068-1072, doi:10.1126/science.1128845, 2006.

O’Neill, B. C., Kriegler, E., Ebi, K. L., Kemp-Benedict, E., Riahi, K., Rothman, D. S., van Ruijven, B. J., van Vuuren, D. P., Birkmann, J., Kok, K., Levy, M., and Solecki, W.: The roads ahead: Narratives for shared socioeconomic pathways describing world futures in the 21st century, Global Environ. Chang., 42, 169-180, doi:10.1016/j.gloenvcha.2015.01.004, 2017.

Peng, X.: China's demographic history and future challenges, Science, 333, 581-587, 2011.

Portmann, F. T., Siebert, S., and Döll, P.: MIRCA2000 - Global monthly irrigated and rain-fed crop areas around the year 2000: A new high-resolution data set for agricultural and hydro- logical modeling, Global Biogeochem. Cy., 24, 1-24, doi:10.1029/2008GB003435, 2010.

RESDC: Data Center for Resources and Environmental Sciences, Chinese Academy of Sciences, The $1 \mathrm{~km}$ grid population dataset and $1 \mathrm{~km}$ grid GDP dataset of China, available at: http://www. resdc.cn, last access: 8 November 2015.

Schewe, J., Heike, J., Gerten, D., Haddeland, I., Arnell, N. W., Clark, D. B., Dankers, R., Eisner, S., Fekete, B. M., ColónGonzález F. J., Gosling, S. N., Kim, H., Liu, X., Masaki, Y., Portmann, F. T., Satoh, Y., Stacke, T., Tang, Q., Wada, Y., Wisser, D., Albrecht, T., Frieler, K., Piontek, F., Warszawski, L., and Kabat, P.: Multimodel assessment of water scarcity under climate change, P. Natl. Acad. Sci. USA, 111, 3245-3250, doi:10.1073/pnas.1222460110, 2014.

Shi, C. X., Zhou, Y. Y., Fan, X. L., and Shao, W. W.: A study on the annual runoff change and its relationship with water and soil conservation practices and climate change in the middle Yellow River basin, Catena, 100, 31-41, doi:10.1016/j.catena.2012.08.007, 2012.

Sterling, S. M., Ducharne, A., and Polcher J.: The impact of global land-cover change on the terrestrial water cycle, Nat. Clim. Change, 3, 385-390, doi:10.1038/NCLIMATE1690, 2013.

Tang, Q. and Oki, T. (Eds.): Terrestrial Water Cycle and Climate Change: Natural and Human-Induced Impacts, American Geo- physical Union (AGU) Geophysical Monograph Series, Vol. 221, John Wiley \& Sons, New Jersey, USA, 2016.

Tang, Q., Oki, T., Kanae, S., and Hu, H.: The influence of precipitation variability and partial irrigation within grid cells on a hydrological simulation, J. Hydrometeorol., 8, 499-512, doi:10.1175/JHM589.1, 2007.

Tang, Q., Oki, T., Kanae, S., and Hu, H.: Hydrological cycles change in the Yellow River basin during the last half of the twentieth century, J. Climate, 21, 1790-1806, doi:10.1175/2007JCLI1854.1, 2008a.

Tang, Q., Oki, T., Kanae, S., and Hu, H.: A spatial analysis of hydroclimatic and vegetation condition trends in the Yellow River basin, Hydrol. Process., 22, 451-458, doi:10.1002/hyp.6624, 2008 b.

Tang, Q., Vivoni, E. R., Muñoz-Arriola, F., and Lettenmaier, D. P.: Predictability of evapotranspiration patterns using remotely sensed vegetation dynamics during the North American monsoon, J. Hydrometeorol., 13, 103-121, doi:10.1175/JHM-D-11032.1, 2012.

Tang, Y., Tang, Q., Tian, F., Zhang, Z., and Liu, G.: Responses of natural runoff to recent climatic variations in the Yellow River basin, China, Hydrol. Earth Syst. Sci., 17, 4471-4480, doi:10.5194/hess-17-4471-2013, 2013.

Wada, Y., van Beek, L. P. H., Viviroli, D., Dürr, H. H., Weingartner, R., and Bierkens, M. F. P.: Global monthly water stress 2: Water demand and severity of water stress, Water Resour. Res., 47, W07518, doi:10.1029/2010WR009792, 2011.

Wada, Y., Wisser, D., and Bierkens, M. F. P.: Global modeling of withdrawal, allocation and consumptive use of surface water and groundwater resources, Earth Syst. Dynam., 5, 15-40, doi:10.5194/esd-5-15-2014, 2014.

Wada, Y., Flörke, M., Hanasaki, N., Eisner, S., Fischer, G., Tramberend, S., Satoh, Y., van Vliet, M. T. H., Yillia, P., Ringler, C., Burek, P., and Wiberg, D.: Modeling global water use for the 21st century: the Water Futures and Solutions (WFaS) initiative and its approaches, Geosci. Model Dev., 9, 175-222, doi:10.5194/gmd-9-175-2016, 2016.

Wang, S. J., Yan, M., Yan, Y. X., Shi, C. X., and He, L.: Contributions of climate change and human activities to the changes in runoff increment in different sections of the Yellow River, Quatern. Int., 282, 66-77, doi:10.1016/j.quaint.2012.07.011, 2012.

Warszawski, L., Frieler, K., Huber, V., Piontek, F., Serdeczny, O., and Schewe, J.: The Inter-Sectoral Impact Model Intercomparison Projection (ISI-MIP): Project framework, P. Natl. Acad. Sci. USA, 111, 3228-3232, doi:10.1073/pnas.1312330110, 2014.

World Bank: The Official Exchange Rate Data of China, available at: http://data.worldbank.org/, last access: 1 December 2015.

$\mathrm{Xu}, \mathrm{J}$. : Variation in annual runoff of the Wudinghe River as influenced by climate change and human activity, Quatern. Int., 244, 230-237, doi:10.1016/j.quaint.2010.09.014, 2011.

Yin, Y., Tang, Q., and Liu, X.: A multi-model analysis of change in potential yield of major crops in China under climate change, Earth Syst. Dynam., 6, 45-59, doi:10.5194/esd-6-45-2015, 2015.

YRCC (Yellow River Conservancy Commission): Comprehensive planning of Yellow River Basin (2012-2030), The Yellow River Water Conservancy Press, Zhengzhou, China, 2013 (in Chinese).

Zhang, C., Zhong, L., Fu, X., Wang, J., and Wu, Z.: Revealing water stress by the thermal power industry in China 
based on a high spatial resolution water withdrawal and consumption inventory, Environ. Sci. Technol., 50, 1642-1652, doi:10.1021/acs.est.5b05374, 2016.

Zhang, H. M., Niu, Y. G., Wang, B. X., and Li, S. M.: The Yellow River water resources problems and countermeasures, Hydrology, 24, 26-31, 2004 (in Chinese).
Zhao, F. F., Xu, Z. X., Zhang, L., and Zou, D. P.: Streamflow response to climate variability and human activities in the upper catchment of the Yellow River Basin, Sci. China Ser. E, 52, 3249-3256, doi:10.1007/s11431-009-0354-3, 2009. 